\title{
LEXICON
}

\section{IN-EQUIVALENT ENGLISH - INDONESIAN TRANSLATION OF COMMISSIVE UTTERANCES IN SOME AMERICAN POPULAR FILMS}

\author{
Anindita Wisesa
}

\begin{abstract}
INTISARI
Skripsi ini meneliti tentang ketidaksetaraan penerjemahan tuturan komisif Bahasa Inggris ke Bahasa Indonesia dalam delapan film popular Amerika. Data yang digunakan dalam penelitian ini adalah 34 tuturan komisif dan subtitel Indonesia yang tidak setara dikumpulkan dari film Easy A, Frozen, Iron Man 2, Black Swan, The Hunger Games, The Dark Knight Rises, Crazy Stupid Love, dan Pitch Perfect. Penelitian in bertujuan untuk menganalisa ketidaksetaraan penerjemahan tuturan komisif Bahasa Inggris ke Bahasa Indonesia yang ditemukan dalam film dan menyarankan terjemahan Bahasa Indonesia yang setara.

12 data perwakilan yang dipilih diklasifikasikan kedalam empat jenis tindak tutur: langsung, tidak langsung, literal dan non-literal. Setiap data akan dianalisis berdasarkan konteks, maksim dalam prinsip kerjasama oleh Grice: kuantitas, kualitas, relevansi, dan pelaksanaan, dan strategi kesopanan oleh Brown dan Levinson: positif dan negatif. Kemudian, penerjemahan yang setara dikemukakan dengan memperhatikan gaya percakapan juga.

Dari data analisis, terjadinya ketidaksetaraan penerjemahan adalah karena perbedaan budaya antara bahasa sumber dan bahasa sasaran yang mempengaruhi produk penerjemahan dan dapat menghasilkan produk penerjemahan yang tidaksetara secara pragmatik.
\end{abstract}

Kata kunci: penerjemahan, komisif, prinsipkerjasama, kesopanan, konteks 


\begin{abstract}
This research attempts to investigate the in-equivalent English into Indonesian translation of commissive utterances in eight American Popular Films. The data used in this research are 34 English commissive utterances and its Indonesian in-equivalent subtitle collected from Easy A, Frozen, Iron Man 2, Black Swan, The Hunger Games, The Dark Knight Rises, Crazy Stupid Love, and Pitch Perfect. In particular, it aims to analyze the inequivalent English-Indonesian translation of commissive utterances found in the films and to propose the equivalent Indonesian translation.

The 12 data representatives chosen are classified into four types of speech acts: direct, indirect, literal, and non-literal. Each of the data is analyzed qualitatively based on the context, Grice's maxims of cooperative principle: quantity, quality, relevance, and manner, and Brown and Levinson's politeness strategies: positive and negative. Then, the equivalent translation is proposed with concerning the style of the conversation too.

Based on the findings, the main problem that causes in-equivalent translation is because the cultural differences between country of source language and target language that affect the translation product that can produce pragmatically in-equivalent translation product.
\end{abstract}

Keywords: translation, commissive, cooperative principles, politeness, context

\section{INTRODUCTION}

Film is a series of moving pictures recorded with sound that tells a story, shown on television or at the cinema or movie theater (Hornby, 2005,p. 573). Many film directors compete to produce films which can be enjoyed by a large group of people, or popular films. Although every film director uses their own native language in their film, it is not a big problem since it can be translated.

Translation helps people communicate and exchange information. Translation is rendering the meaning of a text into another language in the way the author intended the text (Newmark, 1988, p. 5). Nadar (2007) stated that it has to reach accuracy, clarity, correctness, and naturalness in the translation result. He also concludes that there are two problems of translation: cultural and linguistic problems.

Film dialogue usually contains pragmatic aspects, especially speech acts. Searle (1976) examined speech acts and he emphasized illocutionary act as the central study of speech acts. He made a classification of illocutionary act which consists of representative, directive, commissive, expressive, and declaration. Those things cannot be separated from context. As what Mey (2001) said, pragmatics is the study of conditions of human language uses as these are determined by the context of society.

It is interesting to do a research in translation of commissive utterances since the context does matter. The context of conversation has relation with culture of both languages. To understand the context the translator usually also looks at the culture of source and target languages.

This research is limited on the identification of commissive utterances (such as promise, threat, offer and refusal (Searle, 1976)) in Indonesian subtitle of some American popular films which are considered in-equivalent. Searle's classification of illocutionary acts is used to identify the commissive utterance. The inequivalent commissive utterances 
translation is examined using context of the conversation, Grice's maxims of cooperative principles and Brown and Levinson's politeness strategies. After that, the equivalent translation is proposed by paying attention to the context. The data is taken from eight randomly chosen popular American films available in www.imdb.com during 2010-2013accessed on 14 April 2014. They are Easy A, Frozen, Iron Man 2, Black Swan, The Hunger Games, The Dark Knight Rises, Crazy Stupid Love, and Pitch Perfect.

The data were collected by watching the films, reading the film script from the websites or English subtitle and Indonesian subtitle in original VCD or DVD. To find the most accurate data, the dialogue and subtitle were watched carefully. Then, the commissive utterances are listed with the film title, time stamp, context, original translation (subtitle) and suggested translation. The utterances which function as the commissive are printed bold.

Next, the data are classified into direct, indirect, literal, and non-literal speech act to be analyzed qualitatively with the context, Grice's maxims of cooperative principles, Brown - Levinson's politeness strategies, and also concerning the conversation style. The goal of this research is to identify and examine the in-equivalent translation of commissive and propose equivalent Indonesian translation so the meaning can be conveyed properly.

\section{DEFINITION OF TRANSLATION}

Finlay states that a translation may be defined as a presentation of a text in a language other than that in which it was originally written (cited in Nadar, 2007, p. 6). Catford mentions that translation is the replacement of textual material in one language (SL) by equivalent textual material in another language (TL) (cited in Nadar, 2007, p. 7). Nida defines translation as reproducing in the receptor language the closest natural equivalent of the source language message, first in terms of meaning and secondly in terms of style (cited in Nadar, 2007, p. 7). From the definitions above, Nadar (2007) concludes that translation is rendering, reproducing, presenting, or replacing idea of a text from one language into another language with the syntactically, semantically, and pragmatically optimal equivalent meaning in both source and target language. Therefore, in general, translation is transferring idea in the form of words from one language into the other language with the equivalent meaning and natural form in both languages used.

\section{SPEECH ACTS}

Speech acts theory is first proposed by John L. Austin. According to Austin (1962), in some cases when we are saying something, we are also doing something or by saying or in saying something, we are doing something. Austin (1962) divides speech acts into three, (1) locutionary act: the act of saying something, (2) illocutionary act: the act of doing something, and (3) perlocutionary act: the act of convincing someone.

Searle (1976) supports Austin's theory and three classifications of speech acts, but he states that the center study of speech acts is the illocutionary act. Searle classifies illocutionary acts into five: (1) Representative, which commits the speaker to something that is being the case, to the truth of the expressed proposition, for example asserting or concluding; (2) Directive, which attempts by the speaker to get the hearer to do something, for example requesting or questioning; (3) Commissive, which commits the speaker to some future course of action, for example promising, threatening, offering, or refusing; (4) Expressive, which expresses the psychological state specified in the sincerity condition about a state of affairs in the 
propositional content, for example thanking, apologizing, welcoming, or congratulating; and (5) Declaration, which brings about correspondence between the propositional content and reality, for example declaring or naming.

Wijana (2009) classifies the form of speech acts into four: direct, indirect, literal, and non-literal speech acts. He examines that, based on the modus, sentences are divided into three: declarative to give information, interrogative to ask something, and imperative to express invitation, command, or request. Direct speech act is an utterance functioning as what it conventionally functions, while indirect speech acts is an utterance which has different function with the conventional function. He states that literal speech act is an utterance that has the same meaning with the words arranging it, while non-literal speech act is an utterance that has different or contrast meaning with the words arranging it.

\section{CONTEXT}

Mey (2001) defines context as the widest sense that enable the participants in the communication process to interact, and that make the linguistic expression of their interaction intelligible. Since he said that pragmatics are determined by the context of society, studying pragmatics and context cannot be separated. The importance of context in pragmatics is also explained by Yule. He infers that in order to understand pragmatics, the participants need to know the meaning intended in a certain context and how the context affects the utterance. The participants need to know who they are talking to, where, when, and in what situation (Yule, 1996, p. 3-4).

\section{COMMISSIVE SPEECH ACTS}

Essentially, commissive utterance attempts to make the speaker commits to do something for the hearer in the future.
Commissive is illocutionary act whose point is to commit the speaker to some future course of action. Some commissive verbs are shall, intend, and favor (Searle, 1976, p. 356). The direction of fit of commissive is world-to-words and the sincerity condition is intention. The propositional content is that the speaker does some future actions.

Although commissive and directive have the same direction of fit, the point of a promise is to commit the speaker to doing something (and not necessarily to try to get himself to do it and the point of a request is to try to get the hearer to do something (and not necessarily to commit or obligate him to do it) (356). To differentiate it, one would have to show that promises are really a species of requests to oneself or alternatively one would have to show that requests placed the hearer under an obligation. From the Searle's explanation above, Levinson (1983) mentions that paradigm cases of commissive are promising, threatening, offering. FélixBrasdefer (2008) adds that refusal also belongs to the category of commissive because they commit the refuser to perform an action.

\section{MAXIMS OF COOPERATIVE PRINCIPLES}

In order to make the conversation well, the speaker and the hearer should cooperate with each other. Grice (1991) proposes four maxims of cooperative principle that they should follow. They are:

1. Maxim of Quantity: Make your contribution as informative as is required; do not make your contribution more informative than is required.

2. Maxim of Quality:Do not say what you believe to be false; do not say that for which you lack adequate evidence.

3. Maxim of Relevance: Be Relevant. 
4. Maxim of Manner: Avoid obscurity of expression; avoid ambiguity; be brief; be orderly.

\section{POLITENESS STRATEGIES}

In a conversation, face expression is important related to politeness. Face is the public self-image that every member wants to claim for himself (cited in Goody, 1987, p.61). There are two aspects of face, (1) negative face: the basic claim to territories, personal preserves, right to non-distraction and (2) positive face: the positive consistent self-image or personality claimed by the interactants. It is a universal characteristic across cultures that speakers should respect each other' expectations regarding selfimage, take account of their feelings, and avoid Face Threatening Acts (FTAs) (cited in Cutting, 2002, p. 43). Brown and Levinson propose politeness strategies in relation to the concept of face.

\section{Positive Politeness Strategies}

The purpose of this strategy is to save positive face, by demonstrating closeness using some statements such as: friendship, solidarity, and compliment.

Strategy 1: Notice; attend to hearer (his interest, wants, deeds, goods).

Example: "Elsa, you look different... in a good way!" (Taken from Frozen)

Strategy 2: Exaggerate (interest, approval, sympathy, with hearer).

Example: "Well, the truth is, when I look at you, all I see is the White Swan, Yes, you're beautiful, fearful, fragile. Ideal casting." (Taken from Black Swan)

Strategy 3: Intensify interest to hearer to make the hearer involves in the interaction.

Example: "He was charming. A real gentleman." (Taken from Easy A)

Strategy 4: Use in-group identity markers to grow intimacy.

Example: "Honey, what are you trying to say?" (Taken from Crazy Stupid Love)
Strategy 5: Seek agreement by following any information from the hearer.

Example: A: "I had a flat tire on the way home."

$$
\text { B: "Oh God, a flat tire!" }
$$

Strategy 6: Avoid disagreement. Example: A: "What is she, small?"

B: "Yes, yes she is small, not really small but certainly not very big."

Strategy 7: Presuppose/ raise/ assert common ground or similar perception.

Example: A: "Oh, this cut hurts awfully, Mom."

know."

B: "Yes, dear, it hurts terribly, I

Strategy 8: Joke.

Example: "OK If I tackle the cookies now?"

Strategy 9: Assert or presuppose speaker's knowledge and concern for hearer's wants.

Example: "Look, I know you cannot bear parties, but this one will really be good - Do come!"

Strategy 10: Offer, promise.

Example: "I'll be back." (Taken from The Hunger Games)

Strategy 11: Be optimistic.

Example: "You will lend me your lawnmower for the weekend. I hope."

Strategy 12: Include both speaker and hearer in the activity.

Example: "Let's go to Venice, Cipriani."

(Taken from Iron Man 2)

Strategy 13: Give (or ask for) reason.

Example: "Why do I have to wear this?"

(Taken from Frozen).

Strategy 14: Assume or assert reciprocity.

Example: "I'll give you what you need and you do what I tell you to do." (Taken from Iron Man 2)

Strategy 15: Give sympathy to the hearer.

Example: "Just let me know if you need any help."

\section{Negative Politeness Strategies}

The purpose of this strategy is to save the hearer's negative face by 
demonstrating the distance between interlocutors, to avoid imposing or presuming, and to give the hearer's options (Cutting, 2002, p. 45).

Strategy 1: Be conventionally indirect. Example: "Can you pass the marmalade?" (Taken from The Hunger Games)

Strategy 2: Question, hedge to emphasize the sentence.

Example: "You say no a lot, do you?" (Taken from Crazy Stupid Love)

Strategy 3: Be pessimistic and do something carefully.

Example: "Perhaps you'd care to help me."

Strategy 4: Minimize the imposition.

Example: "I just want to know if I can borrow your pen."

Strategy 5: Give deference, for example by using a form of addressee.

Example: "Excuse me, Sir, but would you mind if I close the window?"

Strategy 6: Apologize before requesting or asking something.

Example: "I'm sorry if I bother you, but could you lend me your notes?"

Strategy 7: Impersonalize speaker and hearer.

Example: "Get out!" (Taken from Crazy Stupid Love)

Strategy 8: State the FTA as a general rule. Example: “Just don't leave your stuffs unattended in a public place."

Strategy 9: Nominalize.

Example: "Your good performance on the examinations impressed us favorably."

Strategy 10: Go on record as incurring a debt, or as not indebting hearer.

Example: "Everything would be a lot easier if you give me what we agreed." (Taken from The Dark Knight Rises)
INDONESIAN SUGGESTED

TRANSLATION OF IN-EQUIVALENT

ENGLISH-INDONESIAN

TRANSLATION IN EIGHT

AMERICAN POPULAR FILMS

There are 34 data population of commissive utterances. The data presented below are only four data sample population as the representative of the whole data. Every datum is presented with the time stamp, dialogue, context, original translation (subtitle), suggested translation, and analysis. The commissive utterances are classified based on four types of speech acts: direct, indirect, literal, and non-literal speech acts.

\section{Direct Speech Acts}

Taken from Pitch Perfect, Universal Pictures, California, 2012.

00:30:06-00:30:08 disc 1

Jesse : I'm gonna get you a drink.

Beca : Go for it.

Context:

Jesse, male 20's, is a freshman in a university. $\mathrm{He}$ is a friendly guy. Beca, female 20 's, is a freshman too in the same university. They catch a glance in front of the campus gate. Time goes by and Jesse attracted to Beca as a friend. He likes to talk with Beca in any chance he has. Beca used to feel uncomfortable, but then she finds that Jesse is fun. Beca is forced to join audition for the female a cappella group of the university, The Barden Bellas, by her senior. Similarly, Jesse also joins the audition for the male a cappella group of the university, The Treblemaker. Both of them are accepted. This conversation happens in the school stadium where the new members of school club are introduced. In this conversation, they have not closely related yet to each other, but Jesse wants to attach Beca by offering her to get her a drink. 
Original translation: Aku akan ambil minuman.

Suggested translation: Aku akan ambilkan minum untukmu.

Analysis:

This utterance is a commissive utterance of offering. The speaker uses declarative sentence to state that he wants to get a drink for the hearer. Conventional function of declarative sentence is to state something, so this utterance is included in direct speech act category.

From the maxims of cooperative principle, this utterance follows maxim of quantity and manner. The speaker tells briefly that he wants to get a drink for the hearer. From the politeness strategies, this utterance uses positive politeness strategies number ten, which shows an act of offering. The speaker offers something to the hearer in order to keep the good relationship between them. However, the original translation "Aku akan ambil minuman" is in-equivalent because the translator did not concern to the Indonesian context. In this translation, the utterance contains ambiguity and it does not sound like an offering expression. While in the source language, the speaker's purpose is offering the hearer to get a drink for her. The original translation "Aku akan ambil minuman" is only stating that the speaker wants to get a drink. As the reader, it cannot be known whether the speaker get it for himself or also get it for the hearer or not. The suggested translation will be "Aku akan ambilkan minuman untukmu" because it shows an act of direct offering, just like in the source utterance. Suffix -kan needs to be added after the word ambil because combining both of it presents that the verb ambil is done for someone else (Wirjosoedarmo, 1985, p. 141).

\section{Indirect Speech Acts}

Taken from The Hunger Games, Lionsgate, California, 2012.

01:47:08-01:47:09
Peeta : Well, say something.

Katniss: I'm not good at saying something.

Context:

This conversation happens in the atmosphere of tension, sadness, panic, and a little bit romantic. Peeta, male around 17, is injured and unable to walk. Katniss, female around 17, wants to help him and take care of him inside of a cave. Katniss and Peeta are tributes, from District 12 , to join the Hunger Games, a controlled rough television game in a wild forest arena to fight until death to be the winner prized with fame and wealth. There are 12 districts involved in this game. Each district should select two tributes, male and female, to join this game. They have to fight until death with other eleven couples, unless they want to die inside the arena. This conversation happens in the middle of the game when Katniss finally finds Peeta after days of separation. Peeta's leg was injured and Katniss helps him by guiding him to a cave. Katniss takes care of Peeta. They feel attracted to each other in this scene. Peeta tells Katniss the truth about his feeling.

Original translation: Aku tidak pandai mengatakan sesuatu.

Suggested translation:Aku nggak pintar berkata-kata.

Analysis:

This utterance is a commissive utterance of refusal. The speaker indirectly refuses the hearer by stating something. It is indirect because the function of the declarative sentence used is to state something while in this utterance, the speaker use the declarative sentence to refuse the hearer's request.

This utterance follows maxim of quantity. The speaker does not say that she does not want to say something to respond instead she just say that she is not good in saying something. However, the hearer knows that the speaker does not want to say 
anything about the topic. From politeness strategies, the speaker uses positive politeness strategy number thirteen because the speaker gives reason to the hearer not to say anything instead of directly saying no.

The original translation "Aku tidak pandai mengatakan sesuatu" is considered in-equivalent. Besides the translator translates it word by word, the context in English and Indonesian are different. From the context in English, the speaker says that she is not good in expressing her feeling with words. However, in Indonesian original translation, the utterance shows ambiguity. It raises the readers question what causes the speaker cannot say something. The readers can think that the speaker got sore throat or stutter in speaking. Therefore, after also looking at the style of conversation used and the intimacy between the speaker and the hearer, the suggested translation will be "Aku nggak pintar berkata-kata."

\section{Literal Speech Acts}

Taken from Crazy Stupid Love, Warner Bros Pictures, California, 2011.

00:03:15-00:03:20 disc 1

Emily: The last person in the world that I want to hurt is you.

\section{Cal : If you keep talking, I'm gonna get out of the car.}

Context:

Emily Weaver, a career woman in her 40's, married to Cal Weaver, a boring business man in the same age. This conversation happens on the car when they are going home after having dinner in a restaurant. Unfortunately, Emily asks Cal for a divorce. She admits that she had an affair with her friend at work. Cal is silence and his face looks shocked. Emily asks Cal's opinion for that, but Cal is too shocked to talk. Emily feels guilty about that so she cannot stop talking about the reason and how guilty she is. Cal does not want to hear that and still does not want to say anything. He asks Emily to stop talking, but Emily keeps talking until he says that utterance.

Original translation: Jika kamu terus berbicara, aku akan keluar.

Suggested translation : Kalau kamu terus berbicara, aku akan melompat keluar dari mobil.

\section{Analysis:}

This utterance is commisive utterance of threatening. The speaker uses the utterance to make the hearer must behave in a certain way with mentioning the consequence if the hearer does not do what is told. This utterance is included in literal speech act category because the meaning of the utterance is similar with the words constructing it. The speaker is really getting out of the moving car when he still hears the hearer keeps talking whereas the speaker has already told the hearer to stop speaking.

This utterance follows maxim of quality and manner. The speaker says the truth about the consequence if the hearer does not do what the speaker told her to do. Besides that, the speaker is also clear in his utterance and shows his expression that he feels disappointed, sad, and angry at once. This utterance uses negative politeness strategies number one because the speaker tries to save the hearer negative face by indirectly asking her, by threatening, to stop talking instead of saying in direct way.

The original translation "Jika kamu terus berbicara, aku akan keluar" is considered in-equivalent. If the reader only reads the translation without knowing the context, the reader will not know that the speaker wants to get out of the moving car. This original translation is ambiguous since keluar can be meant getting out from everywhere and does not really show that it is a harmful action. The suggested translation will be "Kalau kamu terus 
berbicara, aku akan melompat keluar dari mobil" that really shows the threat just like in English context.

\section{Non-Literal Speech Acts}

Taken from Frozen, Walt Disney Studio Motion Pictures, California, 2013. 00:11:57-00:11:59 disc 1

Boy : Why do I have to wear this?

Mother: Because the Queen has come of age. It's coronation day.

Boy : That's not my fault.

Context:

This is a conversation between a boy, about 5 or 6 , and her mother as Arandelle's people. This conversation takes place in front of Arandelle's kingdom castle. It happens in the day of Queen of Arandelle, Queen Elsa, birthday and coronation day. The mother asks her son to use appropriate and good clothes because they will come in to the palace to enjoy the celebration of Queen Elsa. However, the boy refuses to change his clothes. He does not like to wear that kind of clothes. He feels like wearing that is a punishment.

Original translation :Ini bukan salahku.

Suggested translation :Aku nggak mau pakai ini.

Analysis:

This utterance is commisive utterance of refusal. The speaker says this in order to refuse the hearer's request. This utterance is categorized as non-literal speech acts because it has different meaning with the words constructing it.

This utterance follows maxim of quantity. The speaker wants to refuse the hearer's request to make him changes his clothes. However, instead of saying that he does not like the clothes, he says that utterance that can also show his refusal. There is no politeness strategy used in this utterance. This utterance is an impolite utterance. It is natural since the speaker is still in the year of five or six and he talks to his own mother. So, he does not really need to use politeness strategies.

The original translation "Ini bukan salahku" is considered in-equivalent. In context of Indonesian, it does not show the refusal. It can be stating or denying something. In the other hand, from the maxims of cooperative principles, this translation is not relevant with the utterance before. To make the translation shows refusal, the suggested translation will be "Aku nggak mau pakai ini."

\section{CONCLUSION}

The results of this research shows that there are 34 in-equivalent translation of commissive utterances found in the film Easy A, Frozen, Iron Man 2, Black Swan, The Hunger Games, Batman: The Dark Knight Rises, Crazy Stupid Love, and Pitch Perfect. Classified based on direct and indirectness type of speech acts, there are 4 direct utterances and 30 indirect utterances. Classified based on literal and nonliteralness type of speech acts, there are 23 literal utterances and 11 non-literal utterances.

The results of this research find that film translator only concern in semantic meaning. Some of the data are translated using word by word translation that will produce the in-equivalent translation products. Some of the translator pays less attention to the context of the conversation and cultural background in the source and target language. Whereas, the cultural differences between the country of source language and target language affect the translation products and context has strong relation with the cultural background of the language.

In relation with the Grice's maxims of cooperative principle, most of commissive utterances follow maxim of manner which are brief and clear. It can be 
found in offering and threatening act. In relation with Brown and Levinson's politeness strategy, offering and refusing acts use positive politeness strategy, while threatening and promising acts use negative politeness strategy. The usage of the Grice's maxims of cooperative principle and Brown and Levinson's politeness strategies is based on the context too. The social status, social distance, and age of the speaker and the hearer and the time and place conversation happened are factors affecting that.

Based on the findings, the main problem that causes in-equivalent English Indonesian translation of commissive utterance is the cultural differences between the country of source language and target language affect the translation products that can produce pragmatically in-equivalent translation products. In order to make the equivalent translation, the translator should pay attention to the context and culture of both source and target language.

\section{REFERENCES}

Austin, John L. How to Do Things with Word.Oxford: Oxford University Press, 1962. Print.

Cutting, Joan. Pragmatics and Discourse: A Resource Book for Students. London: Routledge, 2002. Print.

Félix-Brasdefer, J. César.Politeness in Mexico and the United

States.Amsterdam: John Benjamin Publishing Co. 2008. PDF

File. $<$ http://www.aliexpress.com/ite m/EBOOK-PDF-Politeness-inMexico-and-the-United-States-Acontrastive-study-of-therealization/1780492415.html>.

Fogelman, Dan. "Crazy, Stupid, Love.” The Internet Movie Script Database. February 2010. Web. 7 May 2014. $<$ http://www.imsdb.com/scripts/Craz y,-Stupid,-Love.html>.
Goody, Esther N., ed. Questions and Politeness: Strategies in Social Interaction. Cambridge: Cambridge University Press. 1987. Print.

Grice, Paul. Studies in the Way of Words, pp. 22-40. Massachusetts: Harvard University Press. 1991. Web. 5 June 2014.

$<$ http://courses.media.mit.edu/2004s pring/mas966/Grice\%20Logic\%20a nd\%20Conversation.pdf $>$.

Hornby, A.S. Oxford Advanced Learner's

Dictionary. Oxford: Oxford University Press, 2005. Print.

Khrisna, DyahAyuNila. "The Rude Duryudana and The Tricky Sengkuni." UNS Journal of Language Studies 1.1 (2012): 3-20. Web. 1 June 2014. $<$ http://s3linguistik.pasca.uns.ac.id/w p-content/uploads/2013/03/UNSJOURNAL-OF-LANGUAGESTUDIES-VOL-1.pdf $>$.

Lee, Jennifer. "Disney Frozen: Final Shooting Draft." Walt Disney Animation Studios.September. 2013. Web. 28 April 2014. $<$ http://waltdisneystudiosawards.co $\mathrm{m}$ /downloads/frozenscreenplay.pdf $>$.

Levinson, Stephen C. Pragmatics. Cambridge: Cambridge University Press, 1983. Print.

Mey, Jacob L. Pragmatics: An Introduction. United Kingdom: Blackwell Publishing, 2001. Second Edition. Print.

Nadar, F.X.

PahamdanTerampilMenerjemahkan. Yogyakarta: Unit PenerbitandanPerpustakaanFakultasI 
lmuBudayaUniversitasGadjahMada. 2007. Print.

Newmark, Peter. A Textbook of

Translation. New York: Longman

Group Limited, 1988. PDF

File. $<$ http://www.4shared.com/office /-n3Fvn8n/13_peter_newmark__textbook_of.html?locale=en>.

Polcz, Károly. "Conventionally Indirect

Speech Acts in English-Hungarian

Film Sricpt Translation."

Dissertation Summary of

EötvösLoránd University

(2012).Web. 1 June 2014.

$<$ http://doktori.btk.elte.hu/lingv/polc zkaroly/thesis.pdf $>$.

Royal, Bert V. "Easy A.”The Internet Movie Script Database.August. 2008. Web. 28 April 2014.

$<$ http://www.imsdb.com/scripts/Easy

-A.html>.

Searle, John R. A Classification of Illocutionary Acts. Cambridge:

Language in Society, Vol 5, No, 1 (Apr., 1976), pp. 1-23. Web. 31 May 2014. <http://www.personal.unijena.de/ mu65qev/wikolin/images/2/ 27/Searle_(1975b_1-23).pdf $>$.

---. A Taxonomy of Illocutonary Acts, pp. 344-369. Trier: Linguistic Agency University of Trier. 1976. Web. 27 May 2014.

$<$ http://www.mcps.umn.edu/assets/p df/7.8_searle.pdf $>$.

Springfield. "Iron Man 2 (2010) Movie Script." Web. 1 May 2014.

$<$ http://www.springfieldspringfield.c o.uk/movie_script.php?movie=ironman-2>.

Sultan, Kadhim M. "The Semantics, Pragmatics and Translation of Speech Acts."Journal of College of Basic Education 50 (2007): 24-42.
Al-Mustansiriya University College of Basic Education. Web. 1 June 2014.

$<$ http://www.iasj.net/iasj?func=fullte xt\&aId=10866>.

Wijana, I

DewaPutu.Analisis WacanaPragmati

k: KajianTeoridanAnalisis.

Surakarta: Yuma Pustaka, 2009.

Print.

Wirjsoedarmo, Soekono. Tata

BahasaBahasa Indonesia. Surabaya:

SinarWijaya, 1985. Print.

Yule, George. Pragmatics. Oxford: Oxford University Press, 1996. Print. 